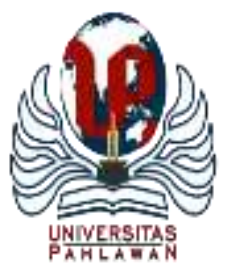

Edukatif : Jurnal Ilmu Pendidikan Volume 4 Nomor 1 Tahun 2022 Halm 1519 - 1527

EDUKATIF: JURNAL ILMU PENDIDIKAN

Research \& Learning in Education

https://edukatif.org/index.php/edukatif/index

\title{
Kesiapan Dosen dalam Meningkatkan Minat Belajar Mahasiswa di Era Covid 19 di STIE Bina Karya
}

\author{
Haya Haratikka ${ }^{凶}$ \\ Sekolah Tinggi Ilmu Ekonomi Bina Karya, Indonesia \\ E-mail : hayaharatikka@gmail.com
}

\begin{abstract}
Abstrak
Menurunnya jumlah mahasiswa aktif per kelasnya merupakan dampak dari perkuliahan secara daring. Untuk menghentikan penularan covid 19, pembatasan sosial menjadi keharusan, termasuk di bidang pendidikan. Beberapa solusi dibuat untuk mengatasi situasi ini tanpa menghentikan proses pendidikan. Kelas luring atau luar jaringan telah berubah menjadi kelas online. Baik dosen maupun mahasiswa harus beradaptasi untuk melanjutkan proses pembelajaran dan menyelamatkan semua orang. Tujuan penelitian ini adalah untuk melihat bagaimana kesiapan dosen dalam meningkatkan minat belajar mahasiswa di tengah pandemi covid 19. Penelitian ini mengambil 55 mahasiswa STIE Bina Karya yang telah mengikuti kelas online selama kurang lebih 3 semester yang diwakili oleh setiap semester. Instrumen dalam penelitian ini berupa kuesioner online yang dibagikan kepada responden. Data yang diperoleh kemudian dianalisis secara desktiptif kualitatif. Hasilnya, minat belajar mahasiswa STIE Bina Karya kembali meningkat perlahan dan mahasiswa STIE Bina Karya menilai bahwa dosen STIE Bina Karya mampu memanfaatkan perangkat untuk proses belajar mengajar. Hal ini diharapkan menjadi satu upaya untuk menarik minat belajar mahasiswa di tengah era pandemi ini. Sehingga jumlah mahasiswa aktif dalam perkuliahan dapat kembali normal seperti sebelum terjadinya wabah Covid 19. Oleh karena itu, dosen perlu meningkatkan kemampuannya dalam menarik minat belajar mahasiswa baik dalam perkuliahan secara daring maupun luring.
\end{abstract}

Kata Kunci: covid 19, kesiapan dosen, minat belajar

\begin{abstract}
The decrease in the number of active students per class is the impact of online lectures. To stop the transmission of COVID-19, social restrictions are a must, including in the field of education. Several solutions were devised to address this situation without stopping the educational process. Offline or online classes have changed to online classes. Both lecturers and students have to adapt to continue the learning process and save everyone. The purpose of this study was to see how the readiness of lecturers in increasing student interest in learning amid the covid 19 pandemic. This study took 55 STIE Bina Karya students who had taken online classes for approximately 3 semesters represented by each semester. The instrument in this study was an online questionnaire that was distributed to respondents. The data obtained were then analyzed through descriptive qualitative. As a result, STIE Bina Karya students' interest in learning is slowly increasing again and STIE Bina Karya students assess that STIE Bina Karya lecturers can use tools for the teaching and learning process. This is expected to be an effort to attract student interest in learning amid this pandemic era. So that, the number of active students in lectures can return to normal as before the Covid 19 outbreak. Therefore, lecturers need to improve their ability to attract student interest in learning both in online and offline lectures.
\end{abstract}

Keywords: covid 19, lecturers' preparedness, learning interest

Copyright (c) 2022 Haya Haratikka

$\triangle$ Corresponding author:

Email : hayaharatikka@gmail.com

DOI : https://doi.org/10.31004/edukatif.v4i1.2261

ISSN 2656-8063 (Media Cetak)

ISSN 2656-8071 (Media Online)

Edukatif : Jurnal Ilmu Pendidikan Vol 4 No 1 Tahun 2022 p-ISSN 2656-8063 e-ISSN 2656-8071 
1520 Kesiapan Dosen dalam Meningkatkan Minat Belajar Mahasiswa di Era Covid 19 di STIE Bina KaryaHaya Haratikka

DOI: https://doi.org/10.31004/edukatif.v4i1.2261

\section{PENDAHULUAN}

Proses pembelajaran merupakan inti dari proses pendidikan yang mengarah pada transformasi kehidupan peserta didik. Dalam proses pembelajaran, guru dan siswa merupakan dua hal esensial yang tidak dapat dipisahkan (Kirom, 2017). Menurut Undang Undang No 20 Tahun 2003, tidak hanya guru, dosen dikategorikan sebagai guru yang telah mengikuti program pendidikan (UU RI, NO.20, 2003). Sebelum covid 19 membuat sekolah ditutup, guru dan siswa melakukan interaksi kelas, namun physical distancing menjadi keharusan di tengah pandemi covid 19 (Kumar et al., 2020). Oleh karena itu, agar sistem pendidikan tetap berjalan, pembelajaran tatap muka kini diganti menjadi pembelajaran online (Gabriel \& Rhonda, 2020). Pembelajaran online atau e-learning adalah situasi yang memaksimalkan penggunaan internet dan perangkat dalam proses pembelajaran (Emadi, 2015) (Atmojo \& Nugroho, 2020). Pemerintah di semua negara menyediakan beberapa platform pembelajaran sebagai sumber daya mereka untuk mendukung peserta didik untuk melakukan kegiatan belajar dari rumah (Cacheiro-Gonzalez et al., 2019), termasuk Indonesia. Kementerian Pendidikan dan Kebudayaan Indonesia memfasilitasi siswa dengan beberapa sumber belajar sehingga guru dan siswa dapat mengaksesnya secara gratis. Platform tersebut adalah Smart Classes, Quipper, Google Indonesia, Sekolahmu, Zenius, dan Microsoft (Abidah et al., 2020). Tujuan dari upaya ini adalah untuk melaksanakan proses belajar mengajar yang efektif di tengah lockdown (Soni, 2020). Baik guru dan peserta didik dapat berkomunikasi melalui sistem ini. Sehingga peserta didik dapat melanjutkan pembelajarannya dengan memanfaatkan teknologi yang ada di tangannya (Sari et al., 2020). Menurut (Žumárová et al., 2010), generasi muda (16-24 tahun) lebih memilih komunikasi elektronik melalui internet. Namun minat belajar siswa di masa pandemi covid 19 semakin rendah karena menghadapi beberapa kendala dalam pelaksanaan pembelajaran online (Azzahra, 2020). Hambatan tersebut berasal dari hambatan personal, teknis, logistik, dan finansial (Abuhammad, 2020). Dalam hal ini, tidak hanya peserta didik, tetapi juga guru sebagai pendidik harus berupaya ekstra untuk menghubungkan antara teknologi, pendidikan dan informasi dalam kebutuhan darurat Covid 19 (Cassibba et al., 2021).

STIE Bina Karya merupakan salah satu perguruan tinggi di Indonesia yang melakukan penutupan selama masa pengereman. Sudah dua semester, pelaksanaan kelas online, melalui Google Classroom (Alim et al., 2019) dan Zoom Meeting (Haqien \& Rahman, 2020). Situasi ini menimbulkan pro dan kontra bagi mahasiswa STIE Bina Karya. Beberapa siswa tidak mempermasalahkan pelaksanaan pembelajaran online tetapi sebagian lagi mempermasalahkannya, karena lokasi mereka di luar jaringan internet, kurangnya dukungan finansial untuk pembelajaran online mereka dan tidak tahu cara mengoperasikan perangkat sistem online. Kondisi ini tentunya berdampak pada minat belajar mereka. Akibatnya IPK mereka menurun, sebagian dari mereka ketinggalan informasi dari dosen, kehilangan kesempatan untuk mendapatkan beasiswa, kemudian tidak sedikit dari mereka yang menyerah dan memutuskan untuk berhenti kuliah. Dalam hal ini, dosen berperan penting dalam meningkatkan minat belajar mahasiswa di masa pandemi ini. Setidaknya siswa dapat menikmati belajar bahkan di kelas online yang memiliki banyak keterbatasan bagi mereka. Dan mereka dapat melanjutkan studi mereka dalam situasi yang tidak terduga ketika virus akan menghilang. Oleh karena itu, permasalahan yang dirumuskan dalam penelitian ini adalah bagaimana kesiapan dosen dalam meningkatkan minat belajar mahasiswa selama masa pandemi di STIE Bina Karya? Adapun tujuan dari penelitian ini adalah untuk melihat capaian dosen STIE Bina Karya dalam meningkatkan minat belajar mahasiswa di masa pandemi ini. Oleh karena itu, hasil penelitian ini bermanfaat akan mendorong dosen dalam proses pengajaran untuk lebih kreatif dan variatif di tengah wabah ini.

Dibanding dengan penelitian sebelunya, penelitian ini berfokus pada kemampuan dosen dalam menarik minat belajar mahasiswa dalam perkuliahan daring. Penelitian ini diharapkan mampu memberikan pandangan kepada dosen akan pentingnya kreatifitas dalam pengajaran terutama dalam masa pandemi ini sebagai upaya peningkatan minat belajar mahasiwa. Sebagaimana pendapat yang diutarakan oleh Argaheni (2020) dalam 
1521 Kesiapan Dosen dalam Meningkatkan Minat Belajar Mahasiswa di Era Covid 19 di STIE Bina KaryaHaya Haratikka

DOI: https://doi.org/10.31004/edukatif.v4i1.2261

penelitiannya, bahwa universitas harus budaya adaptif dalam situasi pandemi ini dengan mengikuti 3 dimensi, yaitu: 1) penciptaan perubahan, 2) tetap memperhatikan mahasiswa, dan 3) pembelajaran organisasi. Masing masing dimensi ini memiliki indikator yang tidak dibahas dalam penelitian ini. Dengan kata lain penelitian ini berfokus pada mahasiswa sedangkan penelitian terdahulu yang menjadi acuan berfokus pada pengajar atau dosen. Adapun yang menjadi urgensi dalam penelitian ini yaitu sebagai acuan bagi pihak kampus dalam membekali dosen untuk melakukan pengajaran yang bisa meningkatkan minat belajar mahasiwa baik dalam perkuliahan luring ataupun daring terutama dalam masa pandemi ini. Sehingga dapat mempertahankan bahkan meningkatkan jumlah mahasiswa yang aktif melaksanakan perkuliahan secara daring.

\section{METODE PENELITIAN}

Penelitian ini merupakan penelitian deskriptif kualitatif yang menggambarkan fenomena yang sebenarnya terjadi di STIE Bina Karya, Indonesia. Selanjutnya, data dikumpulkan melalui observasi, kuesioner berbasis online dan studi pustaka. Kemudian, setelah memperoleh data, peneliti menganalisis data dengan menggunakan teknik deskriptif kuantitatif. Responden penelitian ini adalah 55 mahasiswa STIE Bina Karya yang mewakili seluruh semester (semester 2, 4, 6, dan 8) tahun 2021. Data penelitian ini berupa kombinasi angka dan dijelaskan secara deskriptif berdasarkan indikator kesiapan dosen yang dinilai dalam bentuk skala Likert ( $1-5)$, sangat setuju sampai sangat tidak setuju. Kemudian, data dianalisis dalam bentuk persentase dengan menggunakan rumus statistik deskriptif. Penelitian ini didasarkan pada hal hal apasaja yang dilakukan dosen dalam rangka meningkatkan minat belajar mahasiswa di masa pandemi. Yang menjadi tolok ukur dalam penelitian ini yaitu kesiapan dosen dan jumlah mahasiswa aktif mengikuti perkuliahan.

\section{HASIL DAN PEMBAHASAN PENELITIAN}

Guru yang baik tidak hanya mentransfer materi seperti yang tertulis dalam Rencana Pelaksanaan Pembelajaran atau yang dikenal dengan RPP, tetapi guru bertanggung jawab untuk mengembangkan prinsipprinsip, nilai-nilai, kreativitas, konstruktivisme, kepercayaan diri, keterampilan, dan mengasah berpikir kritis siswa yang baik. Mereka tidak hanya mengajar, guru harus memotivasi, memfasilitasi dan mengevaluasi proses belajar siswa. Oleh karena itu, guru sebagai tenaga pembimbing tidak dapat digantikan oleh orang lain (Polisda, 2017). Hal ini sudah pasti tidak dapat dirasakan oleh peserta didik saat ruang kelas konvensional harus digantikan dengan ruang kelas virtual. Terutama dimasa pandemi sekarang. Mahasiswa diharapkan mampu belajar secara mandiri dirumah (Haratikka, 2020). Pemerintah menggalakkan sistem perkuliahan secara daring atau kelas online untuk membatasi ruang gerak penyebaran virus Covid 19. Selain memberikan dampak positif, penerapan ini juga menimbulkan dampak negatif. Adapun yang menjadi kelemahan penerapan pembelajaran secara online yaitu salah satunya pembelajaran online memberi peluang besar bagi siswa menjadi tidak aktif dalam menyampaikan ide-ide mereka. Berbeda dengan lingkungan belajar semasa sebelum Covid 19 melanda. Ada interaksi antara dosen dengan mahasiswa maupun sesama mahasiswa melalui diskusi tanya jawab dan latihan latihan yang dilakukan setiap pelaksanaan perkuliahan. Ditambah dengan dosen dapat memberikan umpan balik langsung atas pekerjaan mahasiswa dikelas. Ini menjadikan ruang lingkup belajar mahasiswa dikelas menjadi menyenangkan. Sedangkan ketika perkuliahan daring hal ini tidak dirasakan mahasiswa dan dosen. Masing masing terbatas melalui layar monitor handphone atau laptop mereka. Tidak ada diskusi, tanya jawab, sharing, umpan balik dan interaksi secara langsung menjadikan atmosfir belajar menjadi tidak menyenangkan. Apalagi jika dosen memperlakukan mahasiswa secara monoton. Di beberapa kelas ditemukan jumlah penurunan angka mahasiswa yang masih aktif kuliah, sisanya memutuskan untuk tidak melanjutkan perkuliahan mereka. Hal ini tentunya tidak menutup kemungkinan dikarenakan mereka menjadi bosan dalam menjalankan pembelajaran online yang monoton yang sulit untuk dipahami ditambah lagi dengan tugas tugas beserta tenggat pengumpulan tugas yang bersamaan dan hal ini mempengaruhi hasil belajar mereka. Menurunnya perolehan nilai IPK membuat mahasiswa enggan melanjutkan perkuliahannya 
1522 Kesiapan Dosen dalam Meningkatkan Minat Belajar Mahasiswa di Era Covid 19 di STIE Bina KaryaHaya Haratikka

DOI: https://doi.org/10.31004/edukatif.v4i1.2261

dan memilih berhenti kuliah. Ini tentunya menurunkan jumlah mahasiswa di STIE Bina Karya selama pembelajaran daring berlaku. Hal ini sejalan dengan yang diungkaplan oleh Mustafidah \& Suwarsito (2012) bahwa kemauan belajar akan mempengaruhi pencapaian belajar siswa. Oleh karena itu, untuk mencegah hal ini semakin bertambah jumlah mahasiswa yang putus kuliah, mereka membutuhkan pemacu belajar setidaknya untuk mempertahankan minat belajar mereka di tengah pandemi ini (Padma \& Sukanesh, 2011). Hal ini sejalan dengan Yulia bahwa selama masa pandemi siswa harus menyesuaikan kegiatan dan tugasnya sesuai dengan minat dan kondisi siswa dengan mempertimbangkan kesenjangan belajar dan fasilitas rumah mereka yang dilakukan guru sebagai fasilitator (Yulia, 2020).

Menurut Cooper sebagaimana dikutip oleh Yulia ada lima strategi pembelajaran online: 1) terlibat dengan peserta didik secara online, 2) menciptakan lingkungan belajar yang mendukung, 3) menggunakan campuran alat pembelajaran untuk keterlibatan yang lebih baik, 4) memberikan imbalan yang berkelanjutan, 5) membuat konten e-learning mobile (Yulia, 2020). Penjelasan masing masing indikator telah tertuang dalam grafik grafik di bawah ini.

\section{Dosen dapat menarik perhatian siswa \\ 55 tangמה}

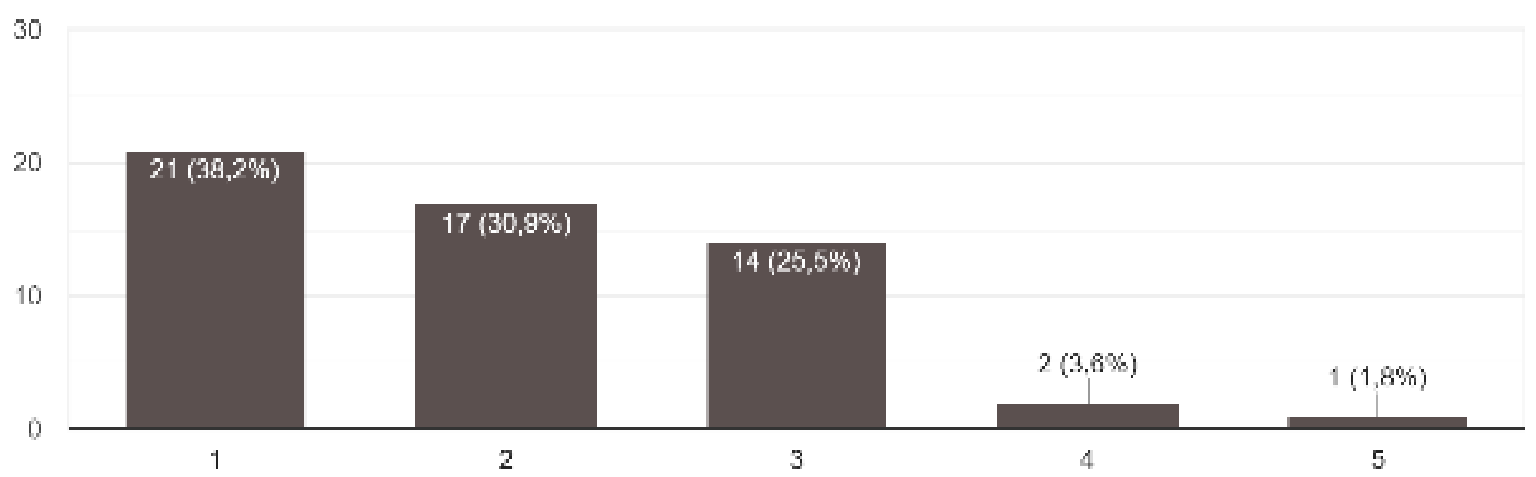

Diagram 1. Kemampuan dosen dalam menarik perhatian mahasiswa

Istilah guru digugu lan ditiru memang menjadi sesuatu yang harus dimiliki setiap pengajar, baik guru maupun dosen. Dosen diharapkan mampu memberikan pelajaran tidak hanya soal materi saja tetapi juga spiritual. Dosen sebagai panutan di dalam kelas maupun di luar kelas atau lingkup sosial harus mampu menjunjung gelar keprofesionalannya selama hidupnya. Apa yang menjadi panutan yaitu cara bertindak melalui gerak maupun kata-kata. Hal ini dapat dilakukan dosen melalui memelihara cara berkomunikasi yang terkontrol dengan penuh perasaan. Menunjukkan kemampuan menjalin komunikasi baik dengan semua kalangan dan mendengar tanpa melihat siapa yang berbicara (Mutawakkil \& Nuraedah, 2019). Tentulah dosen harus mampu berkomunikasi dengan mahasiswa sesuai dengan ilmu yang dimilikinya. Hal ini tentunya untuk menarik perhatian mahasiswa. Dari diagram 1 terlihat kemampuan dosen dalam menarik perhatian mahasiswa cukup baik $(38,2 \%)$. Sekitar 21 mahasiswa mengatakan bahwa bahwa dosen STIE Bina Karya mampu menarik perhatian mahasiswa meski di kelas online. Para dosen berinteraksi dengan mahasiswa melalui Zoom Meeting, Google Classroom, dan grup WhatApp. Mereka membuat cheat dan chat di dalam aplikasi online tersebut kapanpun mereka ingin berdiskusi tentang materi yang mereka miliki pada hari itu. Adapun komunikasi yang diciptakan melalui Zoom Meeting, Google classroom dan Whatsapp sifat dan durasinya berbeda beda. Contohnya saja pada Zoom Meeting yang tergantung oleh sinyal masing masing peserta. Jika pada saat jadwal dilaksanakan Zoom Meeting terjadi gangguan alam seperti hujan atau badai angin maka keadaan kelas virtual bisa saja menjadi buruk. Informasi yang disampaikan dosen terputus putus saat berbicara atau pun terjadi penundaan suara. Jika alam sedang bersahabat maka kelas virtual tidak mengalami kendala. Begitu juga pada komunikasi tulisan yang terjadi pada Google Classroom. Tidak jarang hanya segelintir 
1523 Kesiapan Dosen dalam Meningkatkan Minat Belajar Mahasiswa di Era Covid 19 di STIE Bina KaryaHaya Haratikka

DOI: https://doi.org/10.31004/edukatif.v4i1.2261

mahasiswa yang membacanya. Komunikasi tulisan itu dapat berupa informasi pendukung tugas, kisi-kisi ujian, dan pengumuman yang relevan dengan perkuliahan. Sehingga pada saat dosen menagih tugas atau yang berkenaan dengan informasi yang sudah dosen tuliskan di dinding forum Google Classroom ataupun feedback tugas terlewatkan oleh mahasiswa dengan berbagai alasan. Sedangkan pada komunikasi menggunakan aplikasi whatsapp, kemungkinan untuk mahasiswa membaca pesan yang sudah bertimpah dengan balasan dan pertanyaan dari sesama mahasiswa membuat mereka enggan untuk membaca dan memahaminya. Namun demikian, sebaik mungkin dosen STIE Bina Karya menawarkan kemudahan bagi mahasiwa mahasiswinya untuk menyerap informasi materi perkuliahan. Oleh karena itu, untuk mendukung dan melangsungkan kelas daring dosen harus menguasai cara mengoperasikan perangkat online dan menjalankan platform pembelajaran online (Abuhassna et al., 2020). Menguasai media pembelajaran saja tidak cukup bagi dosen yang melakukan proses pengajaran. Dosen perlu menguasai keterampilan apa yang terbaik dan bagaimana memanfaatkan media tersebut dengan baik. Memilih dan menerapkan media pembelajaran dengan benar. Dengan mempertimbangkan tujuan, materi, metode, evaluasi serta kemampuan guru dan siswa (Coman et al., 2020). Begitu pula dengan dosen STIE Bina Karya dalam berbagai platform pembelajaran online seperti pada diagram 2.

\section{Dosen menggunakan media pembelajaran pendukung setiap mengajar. \\ 55 tanggapan}

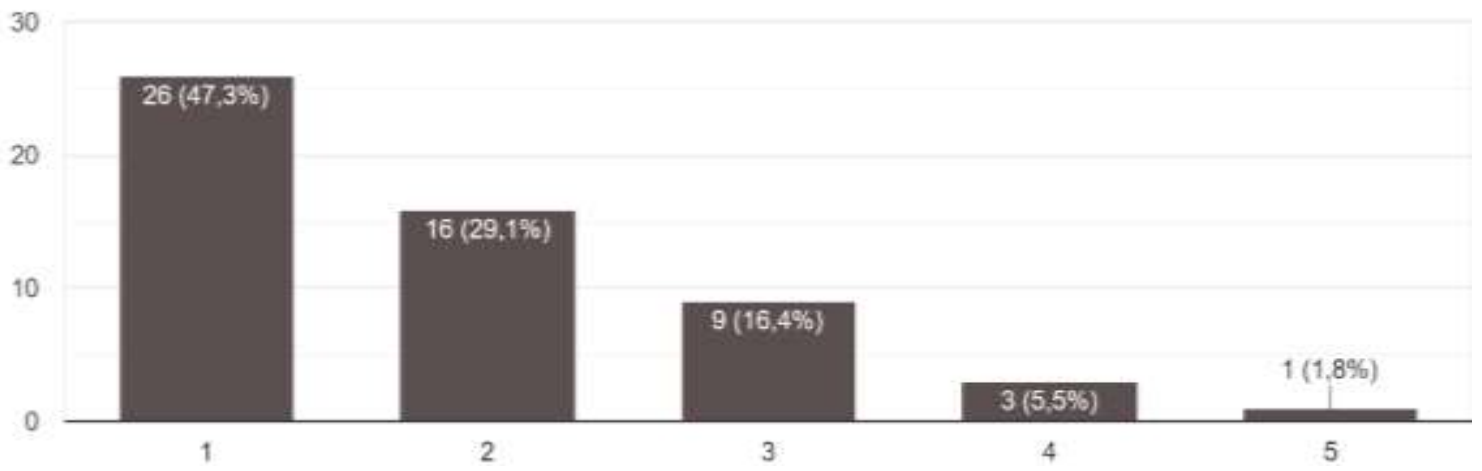

Diagram 2. Penggunaan Media Pembelajaran Online

Tersedianya beberapa media sosial saat ini seperti facebook, whatsapp, twitter, instagram dan lainnya sebagai wadah berkomunikasi baik secara langsung maupun tidak langsung (Sholekah \& Wahyuni, 2019). Sudah tentu pada dewasa ini penggunaan media sosial dilakukan oleh semua kalangan dengan jenjang usia dari anak anak hingga orang dewasa. Media pembelajaran online merupakam media yang tepat di masa pandemi sekarang ini. Dari diagram 2, terdapat 26 mahasiswa $(47,3 \%)$ yang sangat setuju dosennya menerapkan media pembelajaran online untuk menunjang proses pembelajarannya. Media pembelajaran online tersebut seperti whatsapp, Youtube, Facebook, dan Instagram. Adapun penggunaan media online ini yaitu untuk menampilkan video pengajaran dosen dan pengumpulan tugas mahasiwa yang sifatnya praktek. Kemudian, sesama mahasiwa harus mengunjungi akun media sosial teman mereka untuk memberikan komentar dan suka pada video tugas yang mereka sudah unggah di akun media sosial mereka. Dengan demikian, suasana belajar informal memungkinkan untuk meningkatkan niat belajar siswa untuk belajar mandiri (Tan, 2013). Pada akhirnya dosen akan mengarahkan siswa dalam meningkatkan kemampuan mereka untuk fokus pada materi yang diberikan seperti yang diunggah di Google Classroom. 
1524 Kesiapan Dosen dalam Meningkatkan Minat Belajar Mahasiswa di Era Covid 19 di STIE Bina KaryaHaya Haratikka

DOI: https://doi.org/10.31004/edukatif.v4i1.2261

\section{Dalam penggunaan media dapat membantu meningkatkan perhatian mahasiswa dalam kegiatan pembelajaran. \\ 55 tanggapan}

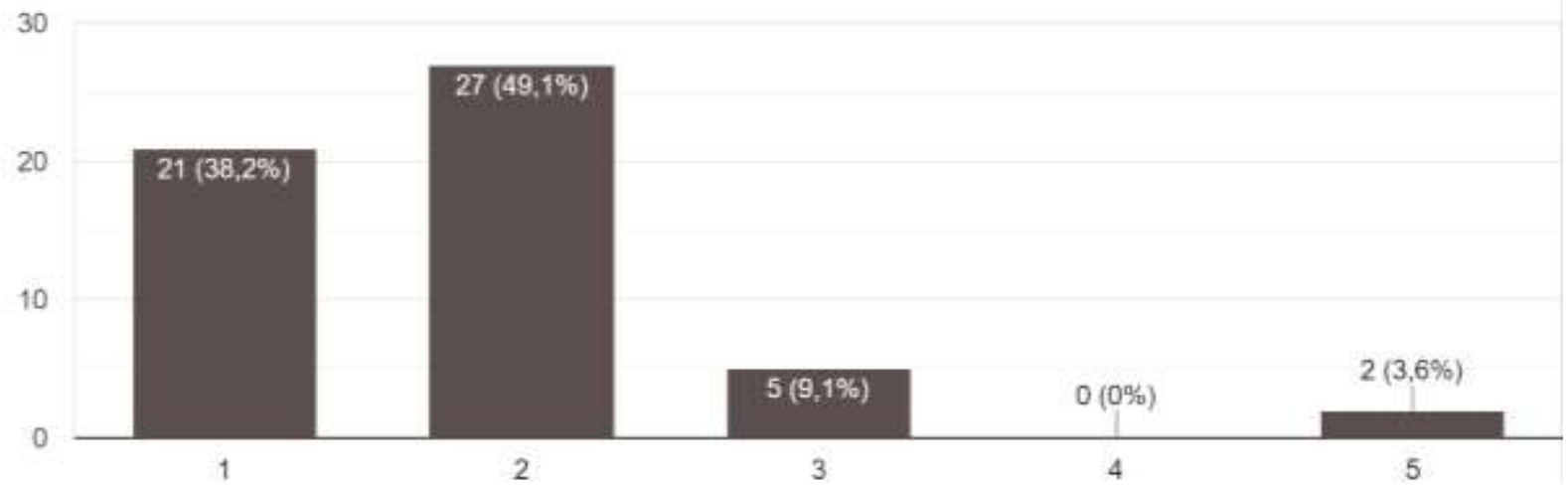

Diagram 3. Penerapan Media Pembelajaran Online Terhadap Perhatian Belajar Siswa

Seperti terlihat pada diagram 3, mahasiswa menyadari betapa pentingnya implementasi media pembelajaran online sebagaimana yang tersebut pada penjelasan diagram 2 . Hal ini terbukti bahwa 49,1\% $38,2 \%$ setuju untuk sangat setuju dengan penerapan media pembelajaran online akan meningkatkan perhatian belajar mereka. Hal ini sejalan dengan penelitian yang telah dilakukan oleh Ramdhani dan Muhammadiyah bahwa media pembelajaran akan mendorong setiap proses pembelajaran (Ramdhani \& Muhammadiyah, 2015). Meski sekolah diliburkan, dosen tetap menjalin komunikasi yang interaktif dengan mahasiswa melalui beberapa media; mengajukan beberapa pertanyaan, memberikan komentar dan umpan balik terhadap hasil karya mahasiswa, mengadakan kuis dan beberapa kegiatan yang berkaitan dengan proses belajar mengajar semua ini dilakukan dengan menerapkan media online.

\section{Dosen memberikan kesempatan kepada mahasiswa untuk bertanya. 55 tanggapan}

60

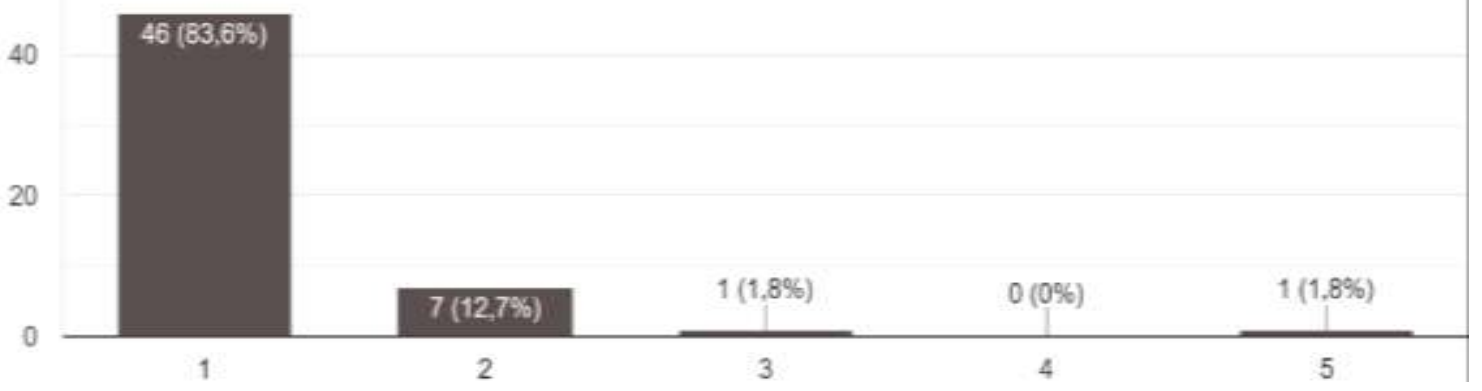

Diagram 4. Kesempatan siswa dalam menanyakan materi

Diagram 4 menjelaskan bahwa dosen memberikan kesempatan kepada mahasiswa untuk mengajukan beberapa pertanyaan terkait bahkan di kelas online. Terdapat 46 siswa $(83,6 \%)$ yang setuju bahwa mereka memiliki kesempatan untuk menanyakan materi yang belum mereka pahami. Boleh dibilang, mahasiswa dibatasi untuk interaksi langsung antar mahasiswa dan antar dosen (Basar, 2021).

Dosen memegang peranan penting dalam menarik minat belajar mahasiswa melalui media pembelajaran dan pengajaran. Kemampuan dosen dalam menjalin komunikasi secara online akan berdampak pada minat belajar mahasiswa di masa pandemi saat ini. Dosen diharapkan mampu menjadi sosok yang menginspirasi dan memberi teladan pendidikan pada mahasiswanya. Sehingga minat belajar mahasiswa akan bergerak positif 
1525 Kesiapan Dosen dalam Meningkatkan Minat Belajar Mahasiswa di Era Covid 19 di STIE Bina KaryaHaya Haratikka

DOI: https://doi.org/10.31004/edukatif.v4i1.2261

yang ditunjukkan dengan indeks komulatif dan angka mahasiswa aktif di kelas. Disamping itu dosen juga perlu melakukan pendekatan secara psikologis kepada mahasiswa. Dan hal ini mungkin dapat dilakukan oleh penelitian selanjutnya mengenai hal hal apa saja yang dapat dilakukan dosen dalam rangka melakukan pendekatan secara psikologis pada mahasiwa yang rentan dengan minat belajarnya.

\section{KESIMPULAN}

Penelitian ini menunjukkan bagaimana kesiapan dosen dalam meningkatkan minat belajar mahasiswa. Untuk menghadapi pandemi ini, baik mahasiswa maupun dosen harus mengubah gaya belajar mengajar, tanpa menghapus, mengubah, dan mengurangi isi materi pembelajaran. Dosen STIE Bina Karya sudah siap menghadapi pandemi ini. Meningkatkan perhatian belajar siswa dengan memadukan media pembelajaran online yang menarik, memberikan waktu untuk bertanya dan aktif melakukan komunikasi interaktif antar siswa. Tersedianya media sosial juga dapat membantu mahasiswa dan dosen dalam melaksanakan tugas tugas perkuliahan. Hal ini jauh lebih bermanfaat dan menarik minat belajar mahasiswa.

\section{REFERENCES}

Abidah, A., Hidaayatullaah, H. N., Simamora, R. M., Fehabutar, D., \& Mutakinati, L. (2020). The Impact of Covid-19 to Indonesian Education and Its Relation to the Philosophy of "Merdeka Belajar." Studies in Philosophy of Science and Education, 1(1), 38-49. https://doi.org/10.46627/sipose.v1i1.9

Abuhammad, S. (2020). Barriers to distance learning during the COVID-19 outbreak: A qualitative review from parents' perspective. Heliyon, 6(11), e05482. https://doi.org/10.1016/j.heliyon.2020.e05482

Abuhassna, H., Al-Rahmi, W. M., Yahya, N., Zakaria, M. A. Z. M., Kosnin, A. B. M., \& Darwish, M. (2020). Development of a new model on utilizing online learning platforms to improve students' academic achievements and satisfaction. International Journal of Educational Technology in Higher Education, 17(1). https://doi.org/10.1186/s41239-020-00216-z

Alim, N., Linda, W., Gunawan, F., \& Saad, M. S. M. (2019). The effectiveness of Google classroom as an instructional media: A case of state islamic institute of Kendari, Indonesia. Humanities and Social Sciences Reviews, 7(2), 240-246. https://doi.org/10.18510/hssr.2019.7227

Argaheni, N. B. (2020). Sistematik Review: Dampak Perkuliahan Daring Saat Pandemi COVID-19 Terhadap Mahasiswa Indonesia. PLACENTUM: Jurnal Ilmiah Kesehatan Dan Aplikasinya, 8(2), 99. https://doi.org/10.20961/placentum.v8i2.43008

Atmojo, A. E. P., \& Nugroho, A. (2020). EFL Classes Must Go Online! Teaching Activities and Challenges during COVID-19 Pandemic in Indonesia. Register Journal, 13(1), 49-76.

https://doi.org/10.18326/rgt.v13i1.49-76

Azzahra, N. F. (2020). Addressing Distance Learning Barriers in Indonesia Amid the Covid-19 Pandemic. Policy Brief, 2, 1-8. https://doi.org/10.6092/unibo/amsacta/6247

Basar, A. M. (2021). Problematika Pembelajaran Jarak Jauh Pada Masa Pandemi Covid-19. Edunesia : Jurnal Ilmiah Pendidikan, 2(1), 208-218. https://doi.org/10.51276/edu.v2i1.112

Cacheiro-Gonzalez, M. L., Medina-Rivilla, A., Dominguez-Garrido, M. C., \& Medina-Dominguez, M. (2019). The learning platform in distance higher education: Student's perceptions. Turkish Online Journal of Distance Education, 20(1), 71-95. https://doi.org/10.17718/tojde.522387

Cassibba, R., Ferrarello, D., Mammana, M. F., Musso, P., Pennisi, M., \& Taranto, E. (2021). Teaching mathematics at distance: A challenge for universities. Education Sciences, 11(1), 1-20. https://doi.org/10.3390/EDUCSCI11010001

Coman, C., Țîru, L. G., Meseșan-Schmitz, L., Stanciu, C., \& Bularca, M. C. (2020). Online teaching and learning in higher education during the coronavirus pandemic: Students' perspective. Sustainability (Switzerland), 12(24), 1-22. https://doi.org/10.3390/su122410367 
1526 Kesiapan Dosen dalam Meningkatkan Minat Belajar Mahasiswa di Era Covid 19 di STIE Bina KaryaHaya Haratikka

DOI: https://doi.org/10.31004/edukatif.v4i1.2261

Emadi, A. (2015). Study e-Learning (Internet-based education) Advances in Environmental Biology. July 2014.

Gabriel, J., \& Rhonda, D. (2020). Students transition from face to face learning to online learning at higher education: A case study in Trinidad and Tobago. Educational Research and Reviews, 15(8), 487-494. https://doi.org/10.5897/err2020.4005

Haqien, D., \& Rahman, A. A. (2020). Pemanfaatan Zoom Meeting untuk Proses Pembelajaran pada Masa Pandemi Covid-19. SAP (Susunan Artikel Pendidikan), 5(1), 51-56. https://doi.org/10.30998/sap.v5i1.6511

Haratikka, H. (2020). Learning English Activity in STIE Bina Karya During the Pandemic. Director, 1(1), $110-117$.

Kirom, A. (2017). Peran Guru Dan Peserta Didik Dalam Proses Pembelajaran Berbasis Multikultural. Jurnal Pendidikan Agama Islam, 3(1), 69-80. http://jurnal.yudharta.ac.id/v2/index.php/pai/article/view/893

Kumar, G., Singh, G., Bhatnagar, V., Gupta, R., \& Upadhyay, S. K. (2020). Outcome of online teachinglearning over traditional education during covid-19 pandemic. International Journal of Advanced Trends in Computer Science and Engineering, 9(5), 7704-7711. https://doi.org/10.30534/ijatcse/2020/113952020

Mustafidah, H., \& Suwarsito. (2012). Analisis Minat Belajar Mahasiswa danTingkat Kehadiran Dosen Pengaruhnya terhadap Tingkat Kelulusan Mahasiswa Menggunakan Fuzzy Quantification Theory ( Analysis of Affect the Learning Interest of Students and Lecturer Attendance Rates against Graduation Th. Juita, II, 85-92.

Mutawakkil, M., \& Nuraedah, N. (2019). Gaya Komunikasi Dosen dalam Pembelajaran Mahasiswa. Communicatus: Jurnal Ilmu Komunikasi, 3(2), 25-42. https://doi.org/10.15575/cjik.v3i2.5765

Padma, A., \& Sukanesh, R. (2011). Meningkatkan Motivasi Belajar Siswa pada Pembelajaran Online Akibat Pandemi COVID-19. Automatic Classification and Segementation of Brain Tumor in CT Images Using Optimal Dominant Gray LLvel Run Length Texture Features, 2(10), 53-59.

Polisda, Y. (2017). “ Thejakartapost” as A Driving Force of Literacy To Enhance Students 'English Skills. $I(1), 344-350$.

Ramdhani, M. A., \& Muhammadiyah, H. (2015). Proceeding International Conference of Islamic Education: Reforms, Prospects and Challenges Faculty of Tarbiyah and Teaching Training The Criteria of Learning Media Selection for Character Education in Higher Education. Proceeding International Conference of Islamic Education: Reforms, Prospects and Challenges Faculty of Tarbiyah and Teaching Training The Criteria of Learning Media Selection for Character Education in Higher Education, 174-182.

Sari, A. B. P., Dardjito, H., \& Azizah, D. M. (2020). EFL students' improvement through the reflective youtube video project. International Journal of Instruction, 13(4), 393-408. https://doi.org/10.29333/iji.2020.13425a

Sholekah, D. D., \& Wahyuni, S. (2019). Pemanfaatan Media Sosial dalam Proses Pembelajaran di SMPN 1 Mojo Kediri. Indonesian Journal of Islamic Education Studies (IJIES), 2(1), 50-60. https://doi.org/10.33367/ijies.v2i1.850

Soni, V. D. (2020). Global Impact of E-learning during COVID 19. SSRN Electronic Journal, June. https://doi.org/10.2139/ssrn.3630073

Tan, E. (2013). Informal learning on YouTube: Exploring digital literacy in independent online learning. Learning, Media and Technology, 38(4), 463-477. https://doi.org/10.1080/17439884.2013.783594

UU RI, NO.20, 2003. (2003). Undang-Undang Republik Indonesia No 20 Tentang Sistem Pendidikan Nasional. Jakarta: Direktorat Pendidikan Menengah Umum, 6. http://stpi-binainsanmulia.ac.id/wpcontent/uploads/2013/04/Lamp_2_UU20-2003-Sisdiknas.doc 
1527 Kesiapan Dosen dalam Meningkatkan Minat Belajar Mahasiswa di Era Covid 19 di STIE Bina KaryaHaya Haratikka

DOI: https://doi.org/10.31004/edukatif.v4i1.2261

Yulia, H. (2020). Online Learning to Prevent the Spread of Pandemic Corona Virus in Indonesia. ETERNAL (English Teaching Journal), 11(1), 48-56. https://doi.org/10.26877/eternal.v11i1.6068

Žumárová, M., Černá, M., \& Maněna, V. (2010). Young generation and their Internet communication. International Conference on Applied Computer Science - Proceedings, October, 313-316. 